\title{
De novo Stage IV Luminal Breast Cancer: Yes or No for Local Treatment? Serial Cases and Review
}

\author{
Marija Karakolevska-llova * * Elena Simeonovska-Joveva², Aleksandar Serafimov ${ }^{3}$ \\ ${ }^{1}$ Department of Oncology, Faculty of Medical Sciences, University Goce Delchev Shtip, Clinical Hospital Shtip, Shtip, \\ Macedonia; ${ }^{2}$ Department of Neurology, Faculty of Medical Sciences, University Goce Delchev Shtip, Clinical Hospital Shtip, \\ Shtip, Macedonia; ${ }^{3}$ Department of Cardiology, Faculty of Medical Sciences, University Goce Delchev Shtip, Clinical Hospital \\ Shtip, Shtip, Macedonia
}

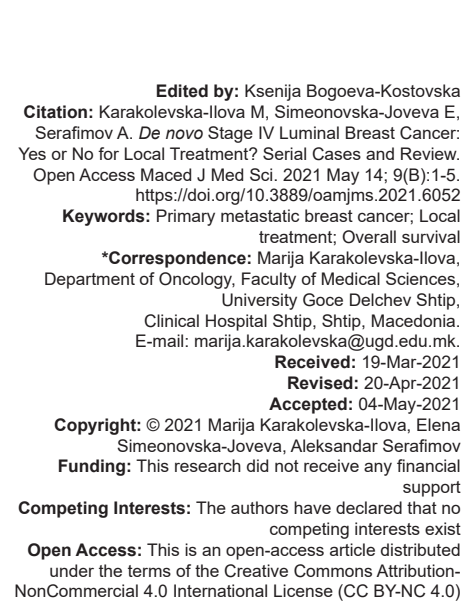

Introduction

Primary metastatic stage IV breast cancer is a relatively rare disease. About $3-5 \%$ of newly diagnosed breast cancer cases are stage IV disease with synchronous metastasis. Metastatic breast cancer is not a curable disease, but according to the development of new therapies, there is an evident prolongation of survival in these patients group. The management of this patient subset mostly comprises systemic therapy, with additional surgery or radiotherapy to control locoregional symptoms and eventually the possibility of increasing the effectiveness of chemotherapy. On the other hand, local treatments may lead to reducing the total tumor burden, restore immunity, eliminate breast cancer stem cells, and decrease the likelihood of resistant disease, which may lower the metastatic potential of the primary tumor.

Most patients with de novo stage IV breast cancer were treated with systemic therapy only because the efficacy of local treatment, such as surgery and/ or radiotherapy, remains controversial and there are still significant differences in the distribution regarding local treatment strategies in these patients. When local treatment is an option, all the factors should be included: Age, performance status, comorbidities, tumor type, and metastatic disease burden.

There are still controversies about the type of local treatment: Surgery and/or radiotherapy, or no local treatment at all. The prospective randomized phase III ABCSG-28 POSYTIVE trial (from 2011 until 2015) evaluated median survival comparing primary surgery followed by systemic therapy to primary systemic therapy in de novo stage IV breast cancer and could not demonstrate an overall survival (OS) benefit for surgical resection of the primary in breast cancer patients presenting with de novo stage IV disease [1].

Surgery for primary metastatic breast cancer was used only for palliation purposes [2]. This approach was demonstrated by many retrospective trials [3], [4], but we still need randomized trials because until now they showed conflict results in favor of primary local therapy or primary systemic therapy. 


\section{Materials and Methods}

This study was a serial of cases. We evaluated the outcome of three patients from their first visit at our clinic (July 2018) until July 2021. The patients were with primary metastatic breast cancer with bone metastases at first presentation.

First case: Woman, 42 years old, premenopausal, unmarried, without comorbidities with locally advanced breast cancer with generalized bone metastases (osteolytic metastases to ribs, cervical and thoracic spine, sternum, and both hips) on bone scan, without visceral metastasis on whole-body computed tomography (CT) scan. The first treatment of choice for this patient was local treatment: Resection of the primary in the breast (total mastectomy and axillary lymph node dissection). According to pathological and $\mathrm{IHH}$ findings from surgical specimen: ductal carcinoma, T2 (3 sm) N1M1, G2, R0L0V0, luminal A type, the patient was set on systemic therapy with hormone therapy (dual blockade with Tamoxifen and $\mathrm{GnRH}$ antagonist) and bisphosphonates.

Second case: Woman, 62 years old, postmenopausal, married, mother of two, without comorbidities with advanced breast cancer with generalized bone metastases (to cervical and thoracic spine and right $6^{\text {th }}$ rib and left $9^{\text {th }} \mathrm{rib}$ ) without any visceral spread. Local treatment with resection of the primary in the breast was first treatment of choice (total mastectomy and axillary lymph node dissection). According to pathological and $\mathrm{IHH}$ findings from surgical specimen: Ductal carcinoma, T2 (4 sm) N2M1, G2, ROL1V0, luminal A type, the patient was set on systemic therapy with hormone therapy/aromatase inhibitor and bisphosphonates.

Third case: Woman, 72 years old, postmenopausal, married, mother of two, without comorbidities with locally advanced breast cancer with generalized bone metastases (osteolytic metastases through whole spine and to both hips). Whole-body CT scan showed metastatic spread to lungs (one solitary metastasis to right lung). The first treatment of choice was the surgery of the breast and removal of lung metastasis. According to pathological findings: ductal carcinoma, T2 (2,5sm) N1M1, G2, ROLOV0, luminal $A$ type, the patient was set on systemic therapy with hormone therapy / aromatase inhibitor and bisphosphonates.

\section{Results}

All three patients were follow-up for 36 months according to the protocol (ultrasound of breast and axilla every 6 months with mammography annually, whole blood examination with breast cancer-related tumor markers every 6 months and abdominal ultrasound every 6 months). All three patients remain alive during follow-up period.

\section{Discussion}

Metastatic breast cancer is a disease with a median OS of 3-year and with 5-year survival rate of only $25 \%$ [5]. OS rate has improved over the years based on the progress of treatment options, which could improve quality of life, reduce tumor burden, and related complications and symptoms.

Conflicting evidence exists regarding the value of surgical resection of the primary in stage IV breast cancer patients [6], [7].

There are many retrospective studies about resection of primary tumor as the first treatment of choice, but they are with conflicting results, which may be related to randomization bias, including different biological types of breast cancer, different metastatic sites, and patients with different menopausal status [8], [9]. Recent retrospective trials have shown a positive impact of local treatment for OS and disease control in primary metastatic breast cancer after primary site tumor resection [10], [11], [12].

A retrospective study of 16023 patients from 1990 to 1993 evaluated the impact of primary local therapy with surgery for OS of de novo stage IV breast cancer. In a multivariate analysis, the number of metastatic sites, the type of metastatic burden, and the extent of resection of the primary tumor were identified as significant independent prognostic covariates. Women treated with surgical resection with free margins, when compared with those not surgically treated, had a superior prognosis, namely the risk of death was reduced by $39 \%$ in patients with negative surgical margins, and the 3 -year survival rate was $35 \%$ compared with $17.3 \%$ in the non-operative group [13].

A more aggressive treatment approach may be appropriate for those patients in whom metastatic disease is limited to a solitary lesion or to multiple lesions at a single organ site. When those patients with local treatment (surgery or radiation) became free of local disease, there might be the potential of achieving a complete remission from chemotherapy, and patients might remain disease-free for prolonged periods of time (15-20 years or more).

A retrospective, population-based cohort study using the 1988-2003 surveillance, epidemiology, and end results program data for 9734 patients with primary metastatic breast cancer after controlling for potential confounding demographic, tumor, and treatment-related 
variables showed that patients who underwent surgery were less likely to die during the study period (OS of 36 months) compared with women who did not undergo surgery (OS of 21 months) [14]. In the study of Singletary et al., available literature from 1992 to 2002 was assessed to determine the role of surgery on survival outcomes and to determine appropriate criteria for selecting the best candidates for surgery and showed that primer surgery could benefit for OS [15].

Several kinds of bias might influence these results, so the data are suggestive and support the need for well-designed clinical trials to determine the exact role of surgical intervention in patients with metastatic breast cancer.

Another population-based retrospective cohort study including 987 patients with primary stage IV breast cancer, stratified according to hormone receptors, HER2 expression, age, and site of metastatic disease was conducted in China between January 2004 and December 2018 and showed that patients who underwent surgery were $54 \%$ less likely to die during the study period than patients who did not. Even among patients who died during follow-up, patients who underwent surgery on their primary breast tumor had longer median survival than those who did not (21.5 vs. 14.0 months $p<0.001$ ) [16].

On the other hand, the study from 2009, which evaluated patients (147) from 1998 until 2005, in a multivariate analysis showed significantly superior survival in the surgery group (HR: $0.47, p=0.003$ mean 4.13 years vs. 2.36 years) compared to non-surgery group. ER and HER2 status were positive predictors of survival $(p<0.0001)$. Central nervous system and liver metastases were adverse predictors $(p=0.059)$. The study showed that benefit was only for patients treated with surgery before diagnosis of metastatic disease and was likely a consequence of stage migration bias [9].

In the retrospective study of Dominici et al., for 609 patients - non-surgery patients were matched to surgery patients on age at diagnosis ( $<55$ vs. $\geq 55$ years), ER status (ER+ vs. ER-), HER2 status (HER2+ vs. HER2-), and number of metastatic sites (1 site vs. $>1$ site) as these variables were thought to be prognostic and related to selection for surgery. The median survival was 3.5 years $(\mathrm{Cl} 2.7-5.0)$ in the surgery group and 3.4 years $(\mathrm{Cl} 3.0-4.0)$ in the non-surgery group. Survival was similar after adjusting for the year of diagnosis, use of trastuzumab, and the presence of any lung metastasis $(\mathrm{HR}=0.94, \mathrm{Cl} 0.83-1.08, p=0.38)$ [17].

Recent published retrospective study of Huang et al. showed that patients in the surgery arm had long survival (median 35 vs. 22 months, $p$ $=0.006)$. In addition, stratified analysis showed that patients with bone metastasis alone or $\leq 3$ metastasis benefit of surgery despite patients with visceral metastasis. ER, PR, and visceral metastasis were independent prognostic factors, but patients who underwent surgery had smaller tumors and less visceral involvement [18].

Local surgery in metastatic breast cancer has become an issue of great controversy since retrospective studies published during recent years suggested a slight benefit from an operative procedure.

The percentage of metastatic breast cancer patients undergoing surgery for the primary tumor in all these series was from $37 \%$ to $61.3 \%$ [19] that shows moving forward of first treatment choice for primary metastatic breast cancer, despite the lack of randomized confirmatory data, giving the value of surgery in the presence of metastatic disease. There were differences in selection criteria of the patients through the studies, so patients undergoing surgery were more likely to be younger, with smaller endocrine responsive tumors, and more often had only a single metastatic site without visceral involvement. Therefore, the benefit of surgery may, at least partially, be attributed to selection biases, such as surgical referral of patients with better general status, less advanced primary tumors, lower burden of metastatic disease, and better response to systemic treatment [20]. Results of multivariate analyses, including all these confounding factors, consistently suggest a survival benefit for optimal local treatment of the primary tumor. A subset of patients with metastatic breast cancer who will benefit from an intensified therapeutic approach might be those with oligometastatic disease, so the population of potentially curable de novo stage IV disease is estimated to be $1 \%-10 \%$ of newly diagnosed metastatic patients [21].

Which patients could benefit most from surgery and what is its optimal timing and the best systemic treatment for these selected patients is the question that still remains [22].

Whether to operate or not on newly diagnosed metastatic breast cancer attracts more and more attention. Based on the results of retrospective studies, there was a need of their confirmation, so the prospective trials were conducted.

In a clinical trial conducted at the M.D. Anderson Cancer Center by Holmes et al. in 1993, patients with solitary metastases were treated with surgical resection with or without radiation therapy, followed by systemic chemotherapy and hormonal therapy. Nearly 25\% of patients were alive without disease 15 years after treatment, and only two additional events occurred at a maximum follow-up of 26 years [23].

In the open-label, randomized controlled study of Badwe et al. was evaluated 350 patients with de novo stage IV breast cancer, stratified by hormone receptor expression, tumor size and type, and number of metastasis. Median follow-up was 23 months and median OS was 19.2 months in the locoregional treatment group and 20.5 months in the no-locoregional treatment group (HR 1.04, 95\% Cl 0.81-1.34; $p=0.79$ ), and the corresponding 2-year OS was $41.9 \%$ in the locoregional treatment group and $43,0 \%$ in the 
Table 1: Retrospective studies

\begin{tabular}{|c|c|c|c|c|c|}
\hline Reference & $\begin{array}{l}\text { Patients } \\
\text { (n) }\end{array}$ & $\begin{array}{l}\text { Period of } \\
\text { diag. }\end{array}$ & Setting & $\begin{array}{l}\text { Primary } \\
\text { surgery }(n)\end{array}$ & Notes and $p$ value \\
\hline $\begin{array}{l}\text { Khan } \\
\text { et al. [13] }\end{array}$ & 16023 & $1990-1993$ & $\begin{array}{l}\text { Population } \\
\text { based }\end{array}$ & $\begin{array}{l}\text { Yes: } 9162 \\
\text { No: } 6861\end{array}$ & $\begin{array}{l}\text { Better } 3 \text {-years survival in } \\
\text { negative margins than in } \\
\text { positive }(p<0.001)\end{array}$ \\
\hline $\begin{array}{l}\text { Gnerlich } \\
\text { et al. [14] }\end{array}$ & 9734 & 1988-2003 & $\begin{array}{l}\text { Population } \\
\text { based }\end{array}$ & $\begin{array}{l}\text { Yes: } 47 \% \\
\text { No: } 53 \%\end{array}$ & $\begin{array}{l}\text { At the study period of } \\
36 \mathrm{~m} \text { patients who underwent } \\
\text { surgery were less likely to } \\
\text { die than women who did not } \\
\text { undergo surgery }(p<0.001)\end{array}$ \\
\hline $\begin{array}{l}\text { Singletary } \\
\text { et al. [15] }\end{array}$ & & 1992-2002 & $\begin{array}{l}\text { Review } \\
\text { of many } \\
\text { studies }\end{array}$ & & $\begin{array}{l}\text { The right criteria for surgery } \\
\text { must be selected in terms } \\
\text { for OS }\end{array}$ \\
\hline $\begin{array}{l}\text { Ma et al. } \\
{[16]}\end{array}$ & 987 & 2004-2018 & $\begin{array}{l}\text { Population } \\
\text { based }\end{array}$ & $\begin{array}{l}\text { Yes: } 463 \\
\text { No: } 524\end{array}$ & $\begin{array}{l}\text { Among patients who died } \\
\text { during follow-up, patients } \\
\text { who underwent surgery on } \\
\text { their primary breast tumor } \\
\text { had a longer median survival } \\
(21.5 \mathrm{~m}) \text { than those who did } \\
\text { not }(14 \mathrm{~m})(p<0.001)\end{array}$ \\
\hline $\begin{array}{l}\text { Bafford } \\
\text { et al. [9] }\end{array}$ & 147 & 1998-2005 & $\begin{array}{l}\text { Population } \\
\text { based }\end{array}$ & $\begin{array}{l}\text { Yes: } 61 \\
\text { No: } 86\end{array}$ & $\begin{array}{l}\text { ER and HER2 status were } \\
\text { independent prognostic } \\
\text { factors for better OS in } \\
\text { surgery group }(p<0.001)\end{array}$ \\
\hline $\begin{array}{l}\text { Dominici } \\
\text { et al. [17] }\end{array}$ & $\begin{array}{l}290 \\
\text { matched }\end{array}$ & 1998-2005 & $\begin{array}{l}\text { Population } \\
\text { based }\end{array}$ & $\begin{array}{l}\text { Yes: } 236 \\
\text { No: } 54\end{array}$ & $\begin{array}{l}3,5 \text {-year survival rate was } \\
\text { similar between groups } \\
(p=0.38)\end{array}$ \\
\hline $\begin{array}{l}\text { Huang } \\
\text { et al. [18] }\end{array}$ & 243 & 2009-2017 & $\begin{array}{l}\text { Hospital } \\
\text { based }\end{array}$ & $\begin{array}{l}\text { Yes: } 125 \\
\text { No: } 118\end{array}$ & $\begin{array}{l}E R, P R \text {, surgical treatment, } \\
\text { and visceral metastasis } \\
\text { remained isolated prognostic } \\
\text { factors for OS }(p<0.006)\end{array}$ \\
\hline
\end{tabular}

no-locoregional treatment group. The study did not demonstrate the superiority of local treatment for OS in primary metastatic breast cancer, but this study also had selection bias because patients with resectable primary tumor in the breast that could be treated with endocrine therapy were randomly assigned upfront, whereas those with an unresectable primary tumor were planned for chemotherapy before randomization [24].

In the multicenter, randomized study of King et al. was included 127 patients who received upfront chemotherapy and $41 \%$ of them received local surgery. The study did not show statistically significant 3-years OS between groups, but the investigators believed that the efficacy of chemotherapy is an important prognostic factor in newly diagnosed metastatic breast cancer patients, and if it is effective than surgery doesn't improve survival furthermore [7].

Table 2: Prospective studies

\begin{tabular}{|c|c|c|c|c|c|}
\hline Reference & $\begin{array}{l}\text { Patients } \\
\text { (n) }\end{array}$ & $\begin{array}{l}\text { Period of } \\
\text { diag.. }\end{array}$ & Setting & $\begin{array}{l}\text { Primary } \\
\text { surgery }(n)\end{array}$ & Notes and $p$ value \\
\hline Holmes et al. [23] & 220 & 1974 & Hospital & Surgery + & 5 -years OS: $39 \%$ versus \\
\hline $\begin{array}{l}\text { Randomized } \\
\text { with untreated } \\
\text { control }\end{array}$ & & 1982 & based & $\begin{array}{l}\text { chemoth. } \\
\text { (FAC) } \\
134 \\
\text { Surgery + } \\
\text { chemoth } \\
\text { (VACP) } 86\end{array}$ & $\begin{array}{l}43 \%, 10-y e a r s \text { OS: } 28 \% \\
\text { and not reached } \\
\text { Median OS: } 80 \% \text { and } \\
\text { not reached }\end{array}$ \\
\hline $\begin{array}{l}\text { Badwe et al. [24] } \\
\text { Open-label } \\
\text { controlled trial }\end{array}$ & 350 & 2005-2013 & $\begin{array}{l}\text { Hospital } \\
\text { based }\end{array}$ & $\begin{array}{l}\text { Yes:173 } \\
\text { No: } 177\end{array}$ & $\begin{array}{l}2 \text {-year OS was } 41.9 \% \\
\text { in the locoregional } \\
\text { treatment group } \\
\text { and } 43.0 \% \text { in the no } \\
\text { locoregional treatment } \\
\text { group }(p=0.79)\end{array}$ \\
\hline $\begin{array}{l}\text { King et al. [7] } \\
\text { Open-label } \\
\text { controlled }\end{array}$ & 127 & 2009-2012 & $\begin{array}{l}\text { Multicenter } \\
\text { based }\end{array}$ & $\begin{array}{l}\text { Yes: } 112 \\
\text { No: } 15\end{array}$ & $\begin{array}{l}\text { Chemotherapy is } \\
\text { effective prognostic } \\
\text { factor, besides study did } \\
\text { not confirm the role of } \\
\text { surgery }\end{array}$ \\
\hline Soran et al. [6] & 274 & $\begin{array}{l}36-40 \\
\text { months }\end{array}$ & $\begin{array}{l}\text { Multicenter } \\
\text { based }\end{array}$ & $\begin{array}{l}\text { Yes: } 138 \\
\text { No: } 136\end{array}$ & $\begin{array}{l}\text { Hazard of death } \\
\text { was } 34 \% \text { lower in } \\
\text { locoregional treatment } \\
\text { group }(p=0.005)\end{array}$ \\
\hline
\end{tabular}

The MF07-01 phase III, randomized, controlled, and multicenter study comparing locoregional treatment followed by systemic therapy with systemic therapy alone for treatment-naïve stage IV breast cancer patients showed $34 \%$ lower Hazard of death in the locoregional treatment group than in the systemic therapy group $(p=0.005)$. The current trial did not show statistically significant improvement in 36-month survival of upfront surgery for stage IV breast cancer patients. However, a longer follow-up study (median, 40 months) showed statistically significant improvement in median survival for upfront surgery in younger patients, bone-only metastasis, and ER-positive patients [6].

Prospective studies did not show any powerful results that would lead the treatment in de novo stage IV breast cancer. They also had few limitations like short follow-up period (between 23-40 months), younger patients, ER-positive/HER2-negative tumors and type of chemotherapy given or not upfront.

Our patients presented in this study had surgery of the primary in the breast as the first treatment of choice. They had a ductal histopathological type, and all of them were LUMINAL A biological type. On the other hand, the tumor size was T2, so the tumor was from $2 \mathrm{sm}$ to $4 \mathrm{sm}$, small tumors that allowed surgery of the primary. Hence, the patients had favorable features according to tumor biology and size and the expectation of better survival. All of them had diffuse osteolytic bone metastasis, but during the evaluation period of 36 months, it did not affect the survival. Our patients with small primary and favorable biological breast cancer type, besides diffuse bone metastasis had benefit from upfront surgery.

Breast cancer is clinically and biologically heterogenic disease, so the outcomes of the Novo stage IV breast cancer vary with molecular subtype (ER, PR, and HER2 status), tumor size, the site of metastatic disease, number of metastatic lesions, effect of systemic therapy and the age of the patient.

\section{Conclusion}

The effect of upfront surgery in newly metastatic breast cancer patients is still challenging, so there is a need to identify the exact cohort of patients who could benefit from surgery. According to this treatment, choice should be derived individually for each patient taking into account his performing status, type of metastasis and the intent of treatment - curative or palliative.

\section{References}

1. Fitzal F, Radisic BV, Knauer M, Steger G, Hubalek M, Balic M Impact of breast surgery in primary metastasized breast cancer: 
Outcomes of the prospective randomized phase III ABCSG28 POSYTIVE trial. Ann Surg. 2019;269(6):1163-9. https://doi. org/10.1097/sla.0000000000002771

PMid:31082916

2. Teshome M. Role of operative management in stage IV breast cancer. Surg Clin North Am. 2018;98(4):859-68.

PMid:30005779

3. Nguyen A, Truong P, Lesperance M, Alexander C, Walter C, Hayashi $\mathrm{E}$, et al. Can locoregional treatment of the primary tumor improve outcomes for women with stage IV breast cancer at diagnosis? Int J Radiat Oncol Biol Phys. 2012;84(1):39-45. https://doi.org/10.1016/j.ijrobp.2011.11.046

PMid:22330986

4. Lane WO, Thomas SM, Blitzblau RC, Plichta JK, Rosenberger LH, Fayanju OM, et al. Surgical resection of the primary tumor in women with de novo stage IV breast cancer: Contemporary practice patterns and survival analysis. Ann Surg. 2019;269(3):537-44. https://doi.org/10.1097/ sla.0000000000002621

PMid:29227346

5. Cardoso F, Spence D, Mertz S, Corneliussen-James D, Sabelko K, Gralow J, et al. Global analysis of advanced/ metastatic breast cancer: Decade report (2005-2015). Breast. 2018;39:131-8. https://doi.org/10.1016/j.breast.2018.03.002 PMid:29679849

6. Soran A, Ozmen V, Ozbas S, Karanlik H, Muslumanoglu M, Igci $\mathrm{A}$, et al. Randomized trial comparing resection of primary tumor with no surgery in stage IV breast cancer at presentation: Protocol MF07-01. Ann Surg Oncol. 2018;25(11):3141-9. https:// doi.org/10.1245/s10434-018-6494-6

PMid:29777404

7. King TA, Lyman JP, Gonen M. Prognostic impact of 21-gene recurrence score in patients with stage IV breast cancer: TBCRC 013. J Clin Oncol. 2016;34(20):2359-65. PMID: 27001590

8. Leung AM, Vu HN, Nguyen KA, Thacker LR, Bear HD. Effects of surgical excision on survival of patients with stage IV breast cancer. J Surg Res. 2010;161(1):83-8. https://doi.org/10.1016/j. jss.2008.12.030

PMid:19375721

9. Bafford AC, Burstein HJ, Barkley CR, Smith LB, Lipsitz S, Iglehart DJ, et al. Breast surgery in stage IV breast cancer: Impact of staging and patient selection on overall survival. Breast Cancer Res Treat. 2009;115(1):7-12. https://doi.org/10.1007/ s10549-008-0101-7 PMid:18581232

10. Xiong Z, Deng G, Wang J, Li X, Xie X, Shuang Z, et al. Could local surgery improve survival in de novo stage IV breast cancer? BMC Cancer. 2018;18(1):885. https://doi.org/10.1186/ s12885-018-4767-x

PMid:30200932

11. Wang W, Liu J, Wang J, Gao J, Wang X, Wang X. Impact of locoregional treatment on prognosis of de novo stage IV breast cancer: A retrospective long-term study of Chinese population. Gynecol Obstet Invest. 2019;84(3):248-58. https:// doi.org/10.1159/000488643

PMid:30448829

12. Desille-Gbaguidi H, Avigdor S, Body G, Ouldamer L. Survival impact of primary site surgery on metastatic breast cancer patients at diagnosis. J Gynecol Obstet Hum Reprod. 2019;48(3):171-7. https://doi.org/10.1016/j.jogoh.2018.10.014 PMid:30352310
13. Khan S, Stewart A, Morrow M. Does aggressive local therapy improve survival in metastatic breast cancer? Surgery. 2002;132(4):620-6. https://doi.org/10.1067/msy.2002.127544 PMid: 12407345

14. Gnerlich J, Jeffe DB, Deshpande AD, Beers C, Zander C Margenthaler JA. Surgical removal of the primary tumor increases overall survival in patients with metastatic breast cancer: Analysis of the 1988-2003 SEER data. Ann Surg Oncol. 2007;14:2187-94. https://doi.org/10.1245/s10434-007-9438-0 PMid: 17522944

15. Singletary E, Walsh G, Vauthey JN, Curley S, Sawaya R, Weber $\mathrm{K}$, et al. A role for curative surgery in the treatment of selected patients with metastatic breast cancer. Oncologist. 2003;8(3):241-51. https://doi.org/10.1634/theoncologist.8-3-241 PMid: 12773746

16. Ma L, Mi Y, Cui S, Wang H, Fu P, Yin Y, et al. Role of locoregional surgery in patients with de novo stage IV breast cancer: Analysis of real-world data from China. Sci Rep. 2020;10(1):18132. https://doi.org/10.1038/s41598-020-75119-0

17. Dominici L, Najita J, Hughes M, Niland J, Marcom P, Wong JN, etal. Surgery of the primary tumor does not improve survival in stage IV breast cancer. Breast Cancer Res Treat. 2011;129(2):459-65. https://doi.org/10.1007/s10549-011-1648-2

\section{PMid:21713372}

18. Huang Z, Tan $Q$, Qin $Q$, Mo Q, Wei C. Impact of Primary site surgery on survival of patients with de novo stage IV breast cancer. Cancer Manag Res. 2021;13:319-27. https://doi. org/10.2147/cmar.s280470

PMid:33469374

19. Khan SA. Does resection of an intact breast primary improve survival in metastatic breast cancer? Oncology (Williston Park). 2007;21(8):924-31.

PMid:17715695

20. Morrow M, Goldstein L. Surgery of the primary tumor in metastatic breast cancer: Closing the barn door after the horse has bolted? J Clin Oncol. 2006;24(18):2694-6. https://doi. org/10.1200/jco.2006.05.9824

PMid: 16702578

21. Hanrahan EO, Broglio KR, Buzdar AU, Theriault LR, Valero V, Cristofanilli $\mathrm{M}$, et al. Combined-modality treatment for isolated recurrences of breast carcinoma: Update on 30 years of experience at the University of Texas M.D. Anderson Cancer Center and assessment of prognostic factors. Cancer. 2005;104(6):1158-71. https://doi.org/10.1002/cncr.21305 PMid:16047352

22. Samiee S, Berardi P, Bouganim N, Vandermeer L, Arnaout A, Dent $S$, et al. Excision of the primary tumour in patients with metastatic breast cancer: A clinical dilemma. Curr Oncol. 2012;19(4):e270-9. https://doi.org/10.3747/co.19.974 PMid:22876156

23. Holmes FA, Buzdar AU, Kau SW, Fraschini G, Ames FC, McNeese MD, et al. Combined-modality approach for patients with isolated recurrences of breast cancer (IV-NED). The M. D. Anderson experience. Breast Med Oncol. 1993;7(1):7-20.

24. Badwe R, Hawaldar R, Nair N, Kaushik R, Parmar V, Siddique S, et al. Locoregional treatment versus no treatment of the primary tumour in metastatic breast cancer: An open-label randomised controlled trial. Lancet Oncol. 2015;16(13):1380-8. https://doi. org/10.1016/s1470-2045(15)00135-7

PMid:26363985 